\section{STUDY OF EXAPTATION EVIDENCE IN CLINICAL RESEARCH FOR DELIVERING PHARMACEUTICAL INNOVATION}

\section{IINTRODUCTION}

As defined by Gould and Vrba, exaptation is a process that is characterized by the evolution of characteristics, its evolution for other usages, and later co-opted for their current role $(1,5)$. As a synonym for the term exaptation, the term "to co-opt" is frequently used in literature $(2,1)$. Exaptation is an evolutionary mechanism that describes the history of spices, ecosystems, and artifacts $(3,1)$. The same authors explain that the evolution process "function follows form," which further helps scholars understand the theoretical background and settings behind this term. Besides, the importance of exaptation is underlined in literature also in terms of creating/realizing a new function of existed artifact and shown as equally important as a new discovery $(2$, 2). Examples of exaptation are numerous in history, and its contribution has shown as extremely valuable. One of the popular literature examples in presenting exaptation is related to the function of bird feathers (initially developed for isothermal function); microwave ovens discovered based on specific radar waves, discoveries of unexpected new functions of drugs (example of Pfizer PLC drug Viagra), etc. Another interesting historical example worth mentioning is the first surgery performed by Josef Lister (1965), revolutionalizing medicine (by applying antiseptic, carbolic acid to prevent infection) $(3,3)$. By this method, post-surgery mortality was reduced significantly (3). In terms of drug development, there are numerous other examples of the exaptative nature of marketized drugs as Statins use as an immunomodulator (initial function as cholesterol modulator); Nitazoxanide
DOI:

\section{SUMMARY}

Key words: exaptation, drug reposition, pharmaceutical industry, innovation, pharmacoeconomics, research, and development.

Exaptation is a process that is characterized by the evolution of characteristics, its evolution for other usages, and later coopted for their current role. In the pharmaceutical industry, innovations have high potential in terms of competitive advantage and profit but are also connected with high risks associated with costs, time, and uncertainty. To minimize risks, companies frequently choose the strategy of exaptation in terms of redeveloping compounds for use in a different disease. The intention of this research is to provide analysis and quantification (measurement) of drugs that have been exaptated through the process of drug reposition. Results indicate that on level of 6098 clinical studies Phase I, we have observed a total of 659 drugs/substances ( 11\%) that have been used in more than one clinical research for the same or different indication showing the level of exaptation use in clinical research.

\footnotetext{
'Inventis CTC, Francois Grosso 7, Nice, France, e-mail: m.stamenovic@rocketmail.com
} 
use as HA maturation and transport inhibitor (initial function was inhibition of the pyruvate); Metmorfin with the assigned function of Immunomodulator drug (approved for Diabetis Melitus type II), etc. $(4,5)$.

Term exaptation was initially explained through the theory of evolution and has been further dispersed to multiple disciplines as the history of technology; innovation studies, anthropology, psychology, linguistics, architecture. Newer studies also show an application of this term to a broader field of economics and Science/education studies.

For the current research, one of the intriguing comments showing the direction of this research was provided by Prata et al., explaining the requirement for further research contributing to the evaluation of pharmaceutical innovation and its economic impact considering adequate innovation classification factors $(5,5942)$. Thinking of exaptation as a process of bringing innovation to market, renovating - a radical and semi-radical innovation affects the construction of new market niches. There is evidence of robust connectivity between exaptated innovation and new market niche construction. Also, Adriani and Cattani explain the importance of measuring exaptation. At the same time, Dew and Sarashvati mention the blockbuster example of Viagra and the role of Pfizer PLC in the construction of a new market niche for erectile dysfunction drugs (3); (5). In the case of Viagra, the drug was exapted, and brought another function (medical indication) was brought to the light of patients and medical professionals.

This research deals with the assessment of exaptation, and more precisely, we are dealing with the drug repurposing process in clinical development that has exaptative character. For this research, drug repositioning is of importance, and by definition, it represents "the process of redeveloping a compound for use in a different disease" $(8,267)$. Additionally, Medina Franco et al. are explaining that: "Process of drug repurposing is an approach to accelerate the drug discovery process by identifying a novel clinical use for an existing drug approved for a different indication." $(8,268)$.

This research deals with repositioning drugs for which exaptative nature was observed as explained in the following sections.

\section{BARRIERS FOR DRUG DEVELOPMENT THAT LEADS INTO STRATEGY FOR DRUG REPURPOSING}

For this research, risks and barriers for entering new drug development processes are important as those are connected with a strategy for drug repurposing. Risk in the pharmaceutical drug development process is high, and analysis performed by Maz- 
zucato and Tancioni shows that $1 / 10.000$ compounds were marketized (9). Success in clinical drug development is highly costly and inefficient. DiMasi et al. performed an in-depth analysis of costs and efficiency of clinical trials (Phase I-IV). They provided an overall estimation of clinical success to $11.83 \%$ (i.e., likelihood that drug enters clinical testing will be approved) (10). On the other hand, the authors concluded that the distribution rate of failures for the observed studies was $44.9 \%$ (Phase I), $43.5 \%$ (Phase II), and $10.6 \%$ (Phase III). Also, pre-human testing of new drug/molecule for out-of-pocket and capitalized (COC) has been estimated at 430 and 1098 million US dollars (2013), respectively. Regarding costs (out of pocket and COC, respectively), clinical research costs were calculated as 965 and 1460 million USD $(11,25)$.

When companies (drug development initiators/sponsors) assess such analysis, they are aware of the density of barriers to innovation development. High costs and uncertainty are common reasons for back through numerous drug development processes, which should be improved in the future. Barriers to innovation development are the reason why companies are choosing a strategy for drug repositioning in order to avoid high costs and uncertainty in terms of product safety.

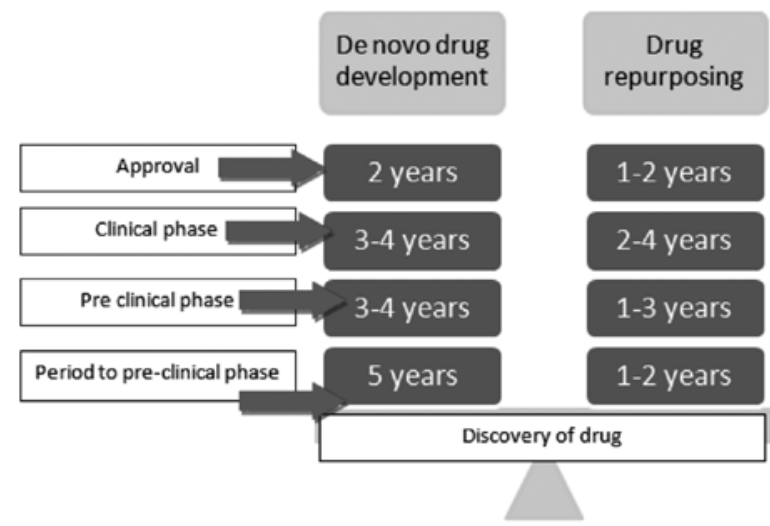

Figure 1. De novo versus drug repurposing drug innovation delivery $(11,4)$

The pharmaceutical industry is relevant for this research due to its characteristics in the drug development and marketization process. Namely, Adriani et al. identified the importance of the pharmaceutical industry in exaptation research as regulatory requirements are strict and internationalized in terms of functions for each drug (artifact) (3). This is particularly important when trying to measure exaptation of off-label drugs (authors are suggesting an area of pharmaceutical research as data might be available due to specific regulatory requirements 
(e.g., by matching and measuring allocated drug functions before and after approval). When it comes to the assessment of exaptation on other levels of the pharmaceutical industry (e.g., starting with in vitro research), comparing patented functions (planned) with later derived functions in the process might also serve as a valid proof of exaptative processes and this might be performed in a wide spectrum of industries (due to patent data availability). Also, the pharmaceutical industry is selected for this research as the potential of exaptation is significant for the expansion of the pharmaceutical industry.

\section{CURRENT METHODS OF EXAPTATION QUANTIFICATION}

Following an extensive literature review, it was noted that measurement and quantification of different aspects of exaptation and its external impact is a process that is ongoing and promising without any conclusions about the best theoretical models that would enable such quantification. Exaptation effects might be measured in different industries, scientific disciplines, explaining a variety of factors. Methods currently provided are within the spectrum from highly complex computer models, Boolean functions searching for similarity problems, use of artificial intelligence and cognitive science, computational modeling of analogy-making up to the validation studies observing and confirming specific impacts of exaptation (12).

For example, Ferreira et al. are dealing with quantification of exaptation in the area of Science/education (2). Their research is based on the fact they mentioned: "relatively little effort has been made to quantify exaptation outside of the topic of biological exaptation" $(2,1)$. As a methodology, authors analyzed the APS dataset (The corpus of Physical Review letters, Physical review, and Review Modern Physics containing of over 450.000 articles) using the Louvain algorithm (for designing alternative classification schemes and clustering of all publications) (2). The method was used in order to determine pairs of publications that cite one another and further for clustering areas of research. As a result, the authors explain that their research should be seen as a preliminary step in the development of a quantitative theory of exaptation.

Another more complex research was based on a quantum model using a similar model as one for proving Hilber space where the researchers were satisfied with providing context for exaptation process that was not "visible" through Kolmogorovian model (14). However, the model was not applicable in reality due to multiple restrictions, showing a further requirement 
for developing models and techniques for evaluation of exaptation as a complex process.

Adriani et al. were measuring exaptation in off label drugs by using FDA NDA's approvals for newly marketized drugs comparing those with later off label use. Very interesting results were obtained in this research based on analysis of 83 NMEs (1998-2000), showing about $42 \%$ were exaptive in nature $(15,335)$.

\section{METHODOLOGY AND RESULTS}

This research is based on an extensive literature review in the area of exaptation, organization management, and innovation development process/management. For analysis, logical induction and deduction were used, including validation study and synthesis of results. In order to answer the major epistemological question: "What is scientific knowledge, and how is it confirmed?" we are providing in-depth literature analysis on the topic of exaptation processes, historical and modern perspective, and structural research and development processes in the pharmaceutical industry. Also, we are providing additional valuable information for further research and measurement of exaptation on innovation. Further, this validation study should contain attributes of formality, rigorousness, and quantifiable from the point of epistemology. Validation is observed terminologically as justification of knowledge claims based primarily on induction and deduction (16). From the epistemological point of view, specific aspects and theories related to exaptation considered its research through reductionist theory, potentially having in mind exaptation as a scientifically derived theme developed first to explain particular segments of the theory of evolution. This epistemological approach is based on the fact that objectivity exists and it is quantifiable.

\begin{tabular}{|l|l|}
\hline 1) Theoretical validity & $\begin{array}{l}\text { 3) Theoretical } \\
\text { performance validity }\end{array}$ \\
$\begin{array}{l}\text { (Research question based } \\
\text { on literature gap analysis) }\end{array}$ & $\begin{array}{l}\text { (example problems solved } \\
\text { with similar method) }\end{array}$ \\
\hline 2) Empirical validity & $\begin{array}{l}\text { 2) Empirical } \\
\text { performance validity }\end{array}$ \\
$\begin{array}{l}\text { (Literature based example } \\
\text { models) }\end{array}$ & $\begin{array}{l}\text { (acceptance of verification } \\
\text { model as appropriate) }\end{array}$ \\
\hline
\end{tabular}

Figure 2. Theoretical framework based on validation square 
In terms of the research question, we followed the literature review and identified interesting and jet unanswered research areas. Namely, Prata et al. explains the existence of wide space for further research that might contribute to evaluating pharmaceutical innovation and its economic impact considering adequate innovation classification factors $(5,5942)$. For this research, drug repositioning is of importance, and by definition, it represents "the process of redeveloping a compound for use in a different disease" $(7,32)$. To quantitatively assess the impact of radical and semi-radical innovations that had exaptative character, we are using counting methods in this extensive exercise to understand how many repurposed drugs (for whom we assured relevant dataset) have been allocated new function.

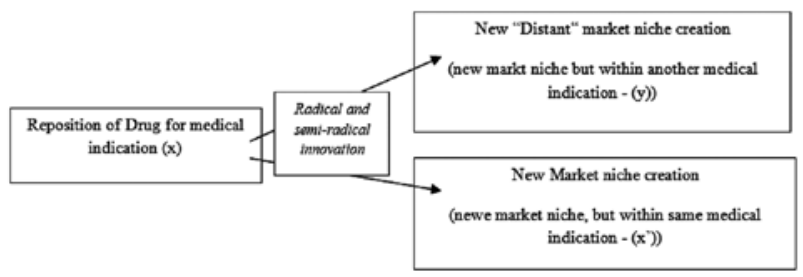

Figure 3. Validation study of exaptation initiated drug repurposing and measuring market distance in new market creation

In this study, a total of 6098 Phase I clinical studies was selected from the clinicaltrials.gov database. Phase I was considered the first-in-human and was therefore chosen as particularly important. After preclinical trials, the innovative substance is tested on humans for the first time. Exaptation is already defined to a certain extent in drug discovery. Still, most of the management research is based on already registered substances (drugs) that have completed the process of clinical trials, including epidemiological studies and verification of medical practice. However, for this study, it was interesting to show trends in at-

Exaptation - adding new function to already known and registered drugs or an as yet unregistered drug in clinical

trials to examine the effect on other functions. tempts by industry and science to use either already known and registered drugs to which a new function is added or an as yet unregistered drug in clinical trials to examine the effect on other functions. The first case is mainly about the so-called off-label use of the drug, which later, through research, comes to scientific confirmation and enters into regulatory flows. There are already existing validation studies about this model of expatiation reflected through repurposing. The second model is more interesting to us as it is proving exaptation in the early stage of innovation development. However, exaptation is carried out by scientists in the process of preclinical studies, and especially concerning the use of artificial intelligence and new technologies in the emergence of new compounds that should be proven as drugs during the next phase - clinical trials. 
When selecting the dataset, the criteria for currently active studies that recruit patients at the time of taking the dataset were used. This selection of studies was made on the basis of criteria for the topicality of data, which is considered important, especially with regard to rapid technological and management development in the field of drug development. Another criterion in the selection of the dataset is that these are early Phase I and Phase I studies and that 6098 studies were selected (dataset is based on the database clinicaltrials.gov). After validation of the data, studies related to medical devices were excluded from the dataset, and 5618 studies remained that investigate already registered drugs for new functions or tested substances that need to be proven to be important in the treatment of certain diseases. When proving the number of drug repurposing uses, substances used within the same indication or with similar indication rules was identified. Analysis was made through extensive exercise and counting of the data based on selected criteria. Once indicated a total number of studies, overlapping results have been indicated in the percentage of the total number.

Following extensive counting, we have observed a total of 659 drugs/supstances that have been used in more than one clinical research for the same or different indication ( $11 \%)$. Even in the case of the same indication, we can discuss the exaptation process derived through drug repurposing. In cases where we have more than one use of the same drug/substance in a variety of indications, we might also discuss the exaptation through drug repurposing. We are acknowledging the certain potential for counting error, especially in terms of database modeling.

However, we have to understand that in certain cases, we have literature more developed than in others. Therefore we have the easier application of new function within the case of thyrosine kinasis inhibitors (17). An example of exaptation in pharmacy may be the drug MasItinib which is a tyrosine kinase inhibitor, and its wider use is already known and explained within the literature. This use had to be demonstrated in clinical trials to demonstrate practical efficacy in a particular therapeutic indication as well as association with toxicity. This inhibitor is used in various diseases in distant classifications of diseases (central nervous system, oncology, inflammatory diseases, etc.). Also, interesting for MasItinib itself is tested, and it is the first anti-cancer drug to be approved in veterinary medicine by the European Medicines Agency. AB Science, a company from France, conducted clinical studies for the drug in the areas of neurodegenerative diseases, inflammatory diseases, and oncology for a number of indications (17).

An example within this study that serves to show the methodological component is also the example of the substance 
DS-3201b, which had application in the Phase I clinical trial on several different indications. This confirmed the exaptation reflected through another repurposing because the tested drug is used multiple times, in relatively distant therapeutic areas according to the ICD classification (ICS-10 Version 2019) (18). ICD classification of diseases presents an international level of classification of diseases and health outcomes delivered by the World Health Organization.

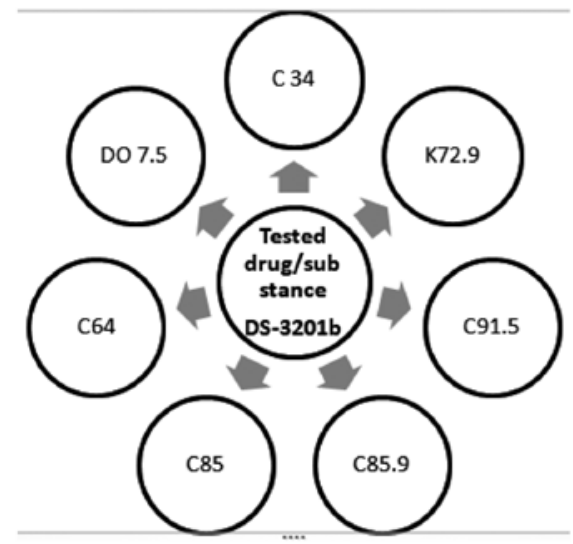

Figure 4. ICD classification of the observed drug repurposing in different clinical research

This drug (with a coded name DS-3201b) is used in the following areas: Small Cell Lung Cancer, Hepatic Impairment, Adult T-cell Leukemia/Lymphoma, Lymphoma, Malignant, Non-Hodgkin Lymphoma, Aggressive Variant Prostate Carcinoma and Metastatic Clear Cell Renal Cell Carcinoma.

We are providing an example of measuring distance in terms of construction of new market niches (whether a new market niche is close to previously assigned drug function - i.e., within the same medical indication (group), or it is more distant - i.e., different medical indication than previously assigned). It is considered that by adding another function to artifact (drug/ molecule) in the drug repurposing process, all drugs (innovations) should be creating new market niches rather than being marketized within the same.

\section{CONCLUSION}

The conclusion is that measurement (quantification) of exaptation requires further development in terms of methods and analysis. We have provided several options in terms of current knowledge and methods for the measurement of exaptation. In 
addition, we are providing results of extensive counting exercises in order to prove the number of the exaptatated pharmaceutical products within the large dataset of more than 6000 clinical research. First-in-human testings must be capable of showing the intention of use of exaptation through drug repurposing whether or not the final pharmaceutical product will be shown as efficient, safe, and later on, marketed. When discussing research contribution, our position is that quantification of drug reposition process might present relevant analysis for further research and understanding of the impact that radical and semi-radical innovations derived through exaptation process have on the creation of new market niches and changing industry scope. Research Limitations and proposals for further research are based on the thoughts that this study assesses another essential aspect of the impact of exaptation measurement in drug early development. However, this study is considered a validation study, although it might have a specific theoretical contribution. Therefore, additional research would be interesting to perform with the use of such data. One of the suggested directions might be exploring the impact of exaptation on speed-to-market in contexts of market uncertainty. An interesting new example shows the relevance of this topic where pandemics of COVID19 have shown emergency in new drug/ vaccine development, and many companies are oriented themselves to previously accumulated knowledge and projects rather than starting de novo drug research.

Managerial implications might be seen in a better understanding of such validity analysis and quantified data (percentage/ share) of radical and semi-radical innovations derived through exaptation. Creating a new market niche is beneficial for newcomers, but also a challenge as large investments should be made in order that product and new market niche is recognized by consumers. Therefore, this study would allow additional insight for decision-makers in the drug discovery industry assessing the level of drug repurposing and its recognition within the industry, mainly oriented within early development phases of the innovation.

\section{LITERATURE}

1. Gould, S. Vrba, E. (1982) Exaptation-a Missing Term in the Science of Form. Paleobiology, 8(1), 4-15. doi:10.1017/S0094837300004310

2. Ferreira et al. (2020) Quantifying exaptation in scientific evolution. Physics and Society. Available at: https://arxiv.org/pdf/2002.08144.pdf, Accessed on 10/02/2021.

3. Andriani, P. et al. (2017) Measuring exaptation and its impact on innovation, search, and problem solving. Organization Science, 28(2), 320-338. doi: 10.1287/orsc.2017.1116. 
ISTRAŽIVANJE

DOKAZA EKSPATACIJE U KLINIČKIM

ISTRAŽIVANJIMA U

KREIRANJU

FARMACEUTSKIH

INOVACIJA

\section{REZIME}

Ključne reči: eksaptacija, repozicija lekova, farmaceutska industrija, inovacije, farmakoekonomija, istraživanja i razvoj.

Eksaptacija je proces koji se odlikuje evolucijom karakteristika artefakta i evolucijom za druge upotrebe koji je kasnije prihvaćen kao njihova nova uloga. U farmaceutskoj industriji inovacije imaju visok potencijal u pogledu konkurentske prednosti i dobiti, ali su takođe povezane sa visokim rizicima povezanim sa troškovima, vremenom i neizvesnošću. Da bi umanjili rizike, kompanije često biraju strategiju eksaptacije u smislu ponovnog razvoja hemijskih jedinjenja za upotrebu kod drugih oboljenja. Namera ovog istraživanja je da pruži analizu i kvantifikaciju (merenje) broja lekova (molekula) koji su „eksaptirani“ kroz proces repozicioniranja lekova. Rezultati ukazuju da smo na nivou od 6098 kliničkih studija, faza I, primetili ukupno 659 lekova / supstanci ( 11\%) koji su korišćeni u više kliničkih istraživanja za istu ili različitu indikaciju koja pokazuje nivo upotrebe eksaptacije u kliničkim istraživanjima.
4. Pizzorno A. et al. (2019) Drug Repurposing Approaches for the Treatment of Influenza Viral Infection: Reviving Old Drugs to Fight Against a Long-Lived Enemy.Frontiers in Immunology. Volume 10.

5. Prata, W. et al. (2017) A Critical Look at Innovation Profile and Its Relationship with Pharmaceutical Industry. International Journal of Scientific Research and Management (IJSRM). Volume 5. Issue. 07. Pp. 5934-5948.

6. Nicholas Dew, Saras D. Sarasvathy (2016) Exaptation and niche construction: behavioral insights for an evolutionary theory, Industrial and Corporate Change, Volume 25, Issue 1, February 2016, Pages 167-179, https://doi.org/10.1093/icc/dtv051.

7. Astin, J.W. et al. (2017). - Innate immune cells and bacterial infection in zebrafish", Methods in Cell Biology. Volume 138, Pages 31-60. Chapter 2.

8. Medina, L. et al. (2015). Epigenetic Technological Applications. -DNA Methyltransferase Inhibitors for Cancer Therapy. Pages 265-290. Chapter 13.

9. Mazzucato, M. and M. Tancioni (2012). R\&D, patents and stock return volatility. Journal of Evolutionary Economics 22: 811-832.

10. Dimasi, J. et al. (2016) Innovation in the pharmaceutical industry: New estimates of R\&D costs. Journal of Health Economics, v. 47, p. 20-33, 2016. DOI10.1016/j.jhealeco.2016.01.012.pp 20-33

11. Pizzorno et al. (2019) Drug Repurposing Approaches for the Treatment of Influenza Viral Infection: Reviving Old Drugs to Fight Against a Long-Lived Enemy. Frontiers in Immunology, Frontiers, 10. Available at:https://hal.archives-ouvertes.fr/hal-02322449/document, Accessed on $01 / 02 / 2021$

12. Arthur, B. Polak, W. (2006) The evolution of technology within a simple computer model. Complexity. Volume 11, Issue 5. Willey. https:// doi.org/10.1002/cplx.20130.

13. Gabora, L. et al. (2011). Progress in Biophysics and Molecular Biology Volume 113, Issue 1, September 2013, Pages 108-116.

14. Andriani, P., Ali, A., \& Mastrogiorgio, M. (2017). Measuring exaptation and its impact on innovation, search, and problem-solving. Organization Science, 28(2), 320-338. DOI: 10.1287/orsc.2017.1116.

15. Barlas, Y. and S. Carpenter, 1990, "Philosophical Roots of Model Validation: Two Paradigms." System Dynamics Review Vol. 6, No. 2, pp. 148-166.

16. Kjartan Pedersen et al. (2000). VALIDATING DESIGN METHODS \& RESEARCH: THE VALIDATION SQUARE. Proceedings of ASME Design Engineering Technical Conferences. September 10-14, 2000, Baltimore, Maryland.

17. ABScience. Available at: https://arxiv.org/abs/1905.11659, Accessed on $01 / 02 / 2021$

18. ICD classification. Available at: https://icd.who.int/browse10/2019/ en, Accessed on 01/02/2021. 